\section{Arterial Hypertension}

Alтhough there are, as yet, no effective means of preventing the occurrence of either arterial hypertension or ischæmic heart disease, much may be done in the individual case to delay or provent the progress and complications of these diseases. A report issued by the World Health Organization dis cusses the various preventive measures that can be applied (Technical Report Series. No. 231: Arterial Hypertension and Ischomic Heart Disease: Preventive Aspects. Pp. 28. Geneva: World Health Organization; London: H.M.S.O., 1962. 1 Swiss franc; 1s. $9 d . ; 0.30$ dollars). It describes standard methods for determining blood pressure and classifies both arterial hypertension and ischæmic heart disease into their main clinical categories and stages, with tho $\checkmark$ iew of identifying those individuals likely to benefit from regular supervision and treatment. A programme of research is suggested, and annexes appended to the report deal with criteria for the differential diagnosis of essential and renal hypertension and with methods for assessing renal function in hypertension.

\section{Cancer Research in Budapest}

THE report of the Research Institute of Oncopathology, Budapest, for 1958-62 contains detailed accounts of the scientific work carried out at the Institute (Pp. 24. Budapest: Research Institute of Oncopathology, 1962). Among the main headlines under which the work of different sections is described are: pathogenesis and morphogenesis; metastasis formation and how it is influenced; autolysis of tumour cells; chemotherapy; the lipid metabolism of tumours and clinico-pathology. Tho roport is published in English, and the Institute's address is Budapest, XII, Rath Gy, u.5, Hungary.

\section{Deprivation of Maternal Care}

BownBY's monograph, Maternal Care and Mental Health, was published by the World Health Organization in 1951, and was at once acclaimed as an unequalled contribution to this subject. Its success is attested to by the frequency with which it has been reprinted and the number of languages into which it has been translated. It has given wide currency to the term 'maternal deprivation' and has influenced the care given to children in institutions, residential nurseries and hospitals in many countries. During the ten years that have elapsed since Bowlby's monograph was published, considerable research has been carried out into various aspects of maternal deprivation. Bowlby's views have been subjected to much eriticism, some of which is based on the often orer-simplified, extreme or distorted interpretations of them prevalent in popular versions, but some of which is constructive and valuable. The result has been that the problem of maternal deprivation can now be seen in a wider perspective than it was in 1951. A volumo in the series Public Health Papers contains a group of papers reviewing the problem of maternal deprivation in this wider perspective (No. 14: Deprivation of Maternal Care: a Reassessment of its Effects. Pp. 165. Genova: World Health Organization; London: H.M.S.O., 1962. 7 Swiss francs; $12 s$; 2.25 dollars). It contains contributions by psychiatrists and specialists in allied disciplines, and also by cultural anthropologists and a writer on social science. The longest contribution is by a fellowworker of Bowlby's, and as the latter has read this paper and agreed with it, it may be taken as representing his present viows on maternal deprivation.

\section{Family Planning Association}

THE remarkable progress of the Family Planning Association during the thirty-one years of its existence is emphasized in two notes in its annual report (Pp. 26. Family Planning Association, 64 Sloane Streot, London, S.W.1, 1962). In its revised declaration on the Christian view of marriage and the family, the Methodist Church condemns careless and improvident begetting of children. While recognizing that some Christians believe that the only legitimate means of conception control is abstinence from intercourse when a child is not desired, the Methodist Church believes that there are other permissible ways of preventing conception, provided that the means used are acceptable to both husband and wife and that, on the best evidence available, they do neither physical nor emotional harm. The declaration goes on to say: "When contraception is chosen as the means of family planning competent medical advice shall be sought, such as that provided by the Family Planning Association". Although during the past few years a number of encouraging statements on this subject have been made by responsible ecclesiastical bodies, the Methodist declaration is the first which has specifically montioned the Family Planning Association. The progress of the Association, as reflected by returns from its branches, is as follows:

$\begin{array}{lrr} & 1960 & 1961 \\ \text { No. of clinics } & 340 & 366 \\ \text { No. of sessions } & 20,733 & 22,246 \\ \text { Tndividual patients } & 212,324 & 284,163 \\ \text { No. of visits or references } & 495,903 & 698,168 \\ \text { New patients } & 89,988 & 90,157 \\ \text { Pre-marital patients } & 14,120 & 16,452 \\ \text { Sub-fertility patients } & 1,567 & 1,836 \\ \text { M.arital difficulty patients } & 1,329 & 1,465\end{array}$

The figures do not include the activities of tho laboratories at the Association's Central Office. Here, during the period under review, 2,132 sub-fertility patients were seen and more than 5,880 pregnancy diagnosis tests were carried out with specimens coming in from as far afield as Bahrein Island and the Persian Gulf. In considering the figure of 16,452 patients, it is noteworthy that 380,000 women were married in England, Scotland and Wales during 1961. The number seeking advice is still very small.

\section{Planning the Future Metropolis}

THE winter 1961 issue of Daedalus, the journal of the American Academy of Arts and Sciences, was devoted to "The Future Motropolis", including articles by $R$. Vernon on the oconomics and finances of the large metropolis, A. Fleisher on the influence of technology on urban forms, E. C. Banfield on the political implications of metropolitan growth, K. W. Deutsch on social communication and the metropolis, and $\mathrm{J}$. Dyckman on the changing uses of the city. About a third of the Proceedings of the American Philosophical Society for June 29, 1962, is devoted to the allied theme of metropolitan planning. Economic aspects of metropolitan planning are discussed by B. Harris; transportation problems and their solution by R. B. Mitchell; the legal basis for reorganizing metropolitan areas in a free society by C. Abrams; and urban form by G. H. Perkins.

\section{Research Careers in the Ministry of Defence, India}

A BOokLeT issued by the Indian Ministry of Defence has the primary object of inviting graduates in technology and engineering, postgraduate re. search workers and other scientists and engineers, to consider the opportunities for taking up a research 